\title{
Pentingnya Tanggung Jawab Dalam Menjaga Persatuan Dan Kesatuan di Kehidupan Sehari - Hari
}

Haniefa Hebatullah

IIK Surya Mitra Husada Indonesia

Haniefa.hebatullah@gmail.com

\begin{abstract}
Abstrak
Persatuan adalah bersatunya macam - macam corak yang beraneka ragam menjadi satu kebulatan yang utuh dan serasi. Persatuan dan kesatuan merupakan kunci suatu negara dalam membangun sebuah bangsa, tanpa adanya rasa tanggung jawab dan kesadaran dalam menjaga persatuan dan kesatuan bangsa maka keadaan suatu negara akan mudah goyah dengan berbagai ancaman baik dalam maupun luar negeri. Oleh sebab itu, masyarakat Indonesia harus memiliki rasa tanggung jawab dan kesadaran dalam menjaga persatuan bangsa Indonesia. Persatuan dan kesatuan didukung oleh pendidikan kewarganegaraan dengan adanya pengajaran tentang toleransi. Toleransi diajarkan dengan cara berkomunikasi dan berdiskusi dengan orang lain yang berbeda. Sikap atau perilaku untuk bekerjasama dan bergotong royong menjadi bentuk konkret untuk menumbuhkan jiwa persatauan dan kesatuan. Dengan demikian persatuan dan kesatauan didukung juga oleh sifat dan sikap yang perlu diterapkan dalam kehidupan sehari-hari. Persatuan itu didorong untuk mencapai kehidupan yang bebas dalam suatu negara yang merdeka dan berdaulat.
\end{abstract}

\section{Latar Belakang}

Indonesia merupakan sebuah negara kepulauan yang terdiri dari beberapa wilayah dan berbatasan langsung dengan beberapa negara luar, yang secara langsung akan membawa dampak bagi berkembangan negara Indonesia terutama perkembangan budaya (Lasabuda, 2013). Bangsa Indonesia dikenal sebagai bangsa majemuk karena memiliki banyak etnis, suku, agama, budaya, dan kebiasaan. Di sisi lain, masyarakat Indonesia juga dikenal sebagai masyarakat multikultural, masyarakat yang anggotanya memiliki latar belakang budaya (cultural background) beragam. Negara Indonesia terdiri lebih dari 500 kelompok etnik atau suku bangsa, 652 bahasa, dan 6 agama. Tidak hanya itu, bangsa Indonesia juga memiliki beragam pepatah, pantun nasihat, cerita rakyat, dan sebagainya. Dari keberagaman yang ada memunculkan suatu pengertian bahwa Indonesia memang dimulai dari adanya keberagaman. Keberagaman tersebut disebabkan karena Indonesia berbentuk kepulauan yang terdiri atas 17.200 pulau dengan 34 provinsi. Hal tersebut mengisyaratkan adanya perbedaan, bila dikelola secara benar, kemajemukan dan multikulturalitas dapat menjadikan negara Indonesia lebih kuat dan lebih maju. Sebaliknya, bila tidak dikelola secara benar maka dapat menimbulkan perpecahan.

Fenomena yang kita rasakan sejak terbukanya era globalisasi yang ditandai dengan masuknya pengaruh nilai - nilai baru dalam semua aspek kehidupan kita serta komitmen bangsa untuk melakukan reformasi di segala bidang telah membawa dampak perubahan 
masyarakat yang sangat besar. Dampak positif yang kita rasakan adalah perkembangan kemajuan ilmu pengetahuan, teknologi dan seni. Sedangkan dampak negatif berkaitan dengan masalah sosial budaya yang menyangkut hal mendasar dari watak dan mentalitas bangsa. Selanjutnya dari berbagai event budaya terlihat bahwa perkawinan budaya saat ini, memperlihatkan kecenderungan akan pengaruh dominan budaya barat terhadap kebudayaan yang telah ada di Indonesia. Masyarakat secara umum yang berinteraksi dengan budaya asing tersebut terus menerus menyerap budaya barat dalam kehidupan kesehariannya sehingga tidak disadari bahwa budaya Indonesia beransur - angsur kehilangan akar budaya dan nilai dasarnya. Kehilangan jati diri atas kebersamaan tersebut menyebabkan terjadinya degradasi kehidupan sosial di mana - mana, munculnya kerusuhan, kemerosotan moral, ketidakpercayaan, kehilangan semangat gotong royong, dsb merupakan dampak yang harus ditanggung bersama.

Seharusnya dengan sikap ke-bhinneka-tunggal-ika-an, rasa kebersamaan yang seharusnya dipupuk dan dibina dalam rangka menuju kemandirian dan kesejahteraan bangsa sesuai dengan tujuan bangsa dalam Pembukaan Undang-Undang Dasar 1945. Dasar budaya "Bhinneka Tunggal Ika" merupakan suatu unsur yang sangat fundamental yang dapat dijadikan bingkai dasar untuk merajut kembali goyahnya jati diri kebudayaan bangsa. Kemudian memahami kembali nilai - nilai kearifan lokal yang tergeser pengaruh dari luar untuk mencari makna ke-Indonesia-an yang sebenar - benarnya dalam arti yang lebih luas sebagai pedoman hidup individu, bermasyarakat, berbangsa dan bernegara.

Suatu bangsa tidak akan maju apabila tidak ada rasa persatuan dan kesatuan dari masyarakatnya untuk secara bersama - sama membangun bangsa. Di dalam kehidupan bernegara istilah - istilah yang masih belum kita ketahui artinya, salah satunya ialah istilah integrasi nasional. Integrasi nasional adalah kesadaran bersama antar sesama warga negara, walaupun berbeda agama, bahasa daerah, dan keragaman lainnya namun hal tersebut tidak menjadi celah untuk sebuah negara tidak bersatu (Muzayanah, 2020). Agar persatuan dan kesatuan dapat berjalan dengan baik, ada beberapa bentuk sikap yang harus dipenuhi yaitu kesadaran mengenai kebutuhan untuk selalu bekerja sama dalam segala hal, harus menjalankan norma persatuan dan kesatuan dengan menumbuhkan rasa saling menghormati dan menghargai setiap perbedaan, melakukan kegiatan - kegiatan yang mengandung unsur persatuan dan kesatuan, dan lain sebagainya.

\section{Kasus / Masalah}

1) Bagaimana cara untuk menjaga persatuan dan kesatuan dalam kehidupan sehari - hari?

2) Apa prinsip yang menjadi pondasi dalam memperkuat persatuan dan kesatuan?

3) Apa manfaat dari terciptanya persatuan dan kesatuan?

\section{Tinjauan Pustaka}

Persatuan berasal dari kata satu yang artinya tidak terpecah - belah atau utuh. Jadi, arti persatuan yaitu bersatunya beraneka macam dan ragam kebudayaan menjadi satu yang utuh dan serasi. Persatuan bangsa berarti gabungan suku-suku bangsa yang sudah bersatu. Dalam 
hal ini, setiap suku bangsa merupakan kelompok masyarakat yang memiliki ciri - ciri tertentu yang bersatu. Penggabungan dalam persatuan bangsa, setiap bangsa tetap memiliki ciri - ciri dan adat istiadat semula. Dalam persatuan bangsa, satu suku bangsa menjadi lebih besar dari sekedar satu suku bangsa yang bersangkutan karena dapat mengatasnamakan bangsa secara keseluruhan.

Kesatuan adalah ke - Esaan, sifat tunggal atau keseutuhan (WJS. Poerwadarminta). Kesatuan bangsa Indonesia, berarti satu bangsa Indonesia dalam satu jiwa bangsa seperti yang diputuskan dalam kongres Pemuda pada tahun 1928 dalam keadaan utuh dan tidak boleh kurang, baik sebagai subjek maupun objek dalam penyelenggaraan kehidupan nasional. Sedangkan kesatuan wilayah Indonesia berarti satu wilayah Indonesia dari Sabang sampai Merauke yang terdiri dari daratan, perairan dan dirgantara diatasnya seperti yang dinyatakan dalam deklarasi Juanda 1957, dalam keadaan utuh dan tidak boleh kurang atau retak.

Pengertian Indonesia ditinjau dari segi geografis berarti bagian bumi yang membentang dari $95^{\circ}$ sampai $141^{\circ}$ Bujur Timur dan $6^{\circ}$ Lintang Utara sampai $11^{\circ}$ Lintang Selatan atau wilayah yang terbentang dari Sabang sampai Merauke. Indonesia dalam arti luas adalah seluruh rakyat yang merasa senasib dan sepenanggungan yang bermukim di dalam wilayah itu. Persatuan dan kesatuan bangsa Indonesia berarti persatuan bangsa yang mendiami wilayah Indonesia. Persatuan itu didorong untuk mencapai kehidupan yang bebas dalam negara yang merdeka dan berdaulat.

Persatuan dan kesatuan merupakan alat yang paling berguna bagi bangsa Indonesia baik dalam rangka merebut, mempertahankan maupun mengisi kemerdekaan. Persatuan mengandung arti "bersatunya macam - macam corak yang beraneka ragam menjadi satu kebulatan yang utuh dan serasi." Persatuan Indonesia berarti persatuan bangsa yang mendiami wilayah Indonesia. Persatuan dan kesatuan bangsa Indonesia yang kita rasakan saat ini terjadi dalam proses yang dinamis dan berlangsung lama karena persatuan dan kesatuan bangsa terbentuk dari proses yang tumbuh dari unsur - unsur sosial budaya masyarakat Indonesia sendiri, yang ditempa dalam jangkauan waktu yang sangat lama. Unsur - unsur sosial budaya tersebut seperti sifat kekeluargaan dan jiwa gotong - royong. Kedua unsur tersebut merupakan sifat - sifat pokok bangsa Indonesia yang dituntun oleh asas kemanusiaan dan kebudayaan.

\section{Pembahasan}

Menurut kamus Ensiklopedi Umum Bahasa Indonesia "Tanggung Jawab" adalah "kewajiban dalam melakukan tugas teretntu". Menurut W.J.S. Poerwodarminto, tanggung jawab adalah suatau yang menjadi kewajiban (keharusan) untuk dilaksanakan, dibahas dan sebagaimya. Sedangkan menurut Drs. Suyadi MP dalam bukunya Ilmu Budaya Dasar menyatakan bahwa "Tanggung Jawab adalah kesadaran manusia akan tingkah laku atau perbuatannya yang disengaja maupun yang tidak disengaja, tanggung jawab juga berarti berbuat sebagai perwujudan kesadaran akan kewajiban”. Tanggung jawab itu sendiri merupakan sifat yang mendasar dalam diri manusia selaras dengan fitrah. Tapi bisa juga tergeser oleh faktor eksternal. Setiap individu memiliki sifat ini, ia akan semakin membaik bila kepribadian orang tersebut semakin meningkat. Ia akan selalu ada dalam diri manusia 
karena pada dasarnya setiap insan tidak bisa melepaskan diri dari kehidupan sekitar yang menunutut kepedulian dan tanggung jawab.

Sebagai sebuah negara kesatuan (unitary state), sudah selayaknya dipahami benar makna "kesatuan" tersebut. Dengan memahami secara benar makna kesatuan, diharapkan seluruh komponen bangsa Indonesia memiliki pandangan, tekat, dan mimpi yang sama untuk terus mempertahankan dan memperkuat kesatuan bangsa dan negara. Filosofi dasar persatuan dan kesatuan bangsa dapat ditemukan pertama kali dalam kitab Sutasoma karya Mpu Tantular. Dalam kitab tersebut terdapat tulisan berbunyi "Bhinneka Tunggal Ika tan hana dharma mangrwa", yang berarti "berbeda - beda tetapi tetap satu, tak ada kebenaran yang mendua". Frasa inilah yang kemudian diadopsi sebagai semboyan yang tertera dalam lambang negara yaitu Garuda Pancasila. Semangat kesatuan juga tercermin dari Sumpah Palapa Mahapatih Gajahmada. Sumpah ini berbunyi: "Sira Gajah Mahapatih Amangkubhumi tan ayun amuktia palapa", sira Gajah Mada: "Lamun huwus kalah nusantara isun amukti palapa, lamun kalah ring Gurun, ring Seran, Tañjung Pura, ring Haru, ring Pahang, Dompo, ring Bali, Sunda, Palembang, Tumasik, samana isun amukti palapa". Terjemahan dari sumpah tersebut kurang lebih adalah: Beliau Gajah Mada Patih Amangkubumi tidak ingin melepaskan puasa. Ia Gajah Mada, "Jika telah mengalahkan Nusantara, saya (baru akan) melepaskan puasa. Jika mengalahkan Gurun, Seram, Tanjung Pura, Haru, Pahang, Dompo, Bali, Sunda, Palembang, Tumasik, demikianlah saya (baru akan) melepaskan puasa". Informasi tentang Kitab Sutasoma dan Sumpah Palapa ini penting untuk menunjukkan bahwa gagasan, hasrat, dan semangat persatuan sesungguhnya telah tumbuh dan berkembang dalam akar sejarah bangsa Indonesia. Namun dalam alam modern-pun, semangat bersatu yang ditunjukkan oleh para pendahulu bangsa terasa sangat kuat. (Budiansyah: 2007)

Warga Negara Indonesia ikut andil dalam membangun persatuan dan kesatuan bangsa, maka kita harus senantiasa berperilaku sesuai dengan norma serta aturan yang telah ditetapkan. Ada beberapa situasi yang menunjukkan berperilaku sesuai peraturan agar persatuan dan kesatuan bangsa tetap tercipta. Pertama adalah tentang menjalin hubungan baik antar sesama warga. Manusia sebagai mahluk sosial sudah pasti membutuhkan orang lain untuk menjalani kehidupan sehari - harinya, baik teman, sahabat, orangtua, keluarga dan lainnya. Hubungan baik antar sesama orang agar jikalau suatu saat kita memerlukan pertolongan kita tidak akan sulit mendapat bantuan dari orang lain (Faliyandra, 2019).

Rasa saling menghormati terhadap perbedaan demi terjalinnya rasa persatuan dan kesatuan bangsa. Jiwa saling menghormati sudah seharusnya ditanamkan sejak usia dini agar dapat diterapkan dikemudian hari. Perbedaan yang ada harus dihormati dan di hargai seperti simbol yang ada pada Negara Indonesia yaitu Bhineka Tunggal Ika yang berarti walaupun berbeda beda tetapi tetap satu jua. Pada dasarnya Indonesia merdeka karena adanya persatuan dan kesatuan tanpa memandang perbedaan, tanpa adanya kesatuan negara akan hancur dan saling menjelek - jelekan dan tidak akan saling menghormati perbedaan. Beberapa contoh menghargai perbedaan atau bertoleransi yaitu:

1. Tidak menjelek - jelekan agama lain 
2. Tidak mengganggu orang yang sedang beribadah

3. Menghormati tradisi dan adat istiadat yang berlaku

4. Iikut menghormati acara keagamaan agama lain

5. Menjalin hubungan baik dengan orang - orang yang memeluk agama berbeda

Menjaga persatuan dan kesatuan dalam keberagaman menjadi tanggung jawab seluruh rakyat Indonesia. Persatuan dan kesatuan penting untuk dijaga dan dipertahankan. Sebab, tanpa persatuan dan kesatuan maka akan timbul perpecahan. Tanpa persatuan dan kesatuan juga tidak mungkin Indonesia dapat berdiri seperti sekarang. Oleh karena itu seluruh warga Indonesia wajib menjaga dan bertanggung jawab terhadap persatuan dan kesatuan.

\section{Kesimpulan}

1) Cara untuk menjaga persatuan dan kesatuan dalam kehidupan sehari - hari beragam, beberapa diantaranya yaitu :

a. Ikut bekerja bakti membersihkan lingkungan sekitar rumah

b. Mengikuti giliran ronda malam atau pos kamling untuk menjaga keamanan lingkungan sekitar

c. Saling tolong menolong

d. Menghargai setiap perbedaan yang ada

e. Menggunakan produk Indonesia

f. Selalu mengenang jasa para pahlawan

Masih banyak lagi cara untuk menjaga persatuan dan kesatuan, namun hal yang terpenting adalah niat dan kesadaran diri dari dalam diri untuk bersama sama bertanggung jawab menjaga persatuan dan kesatuan Bangsa Indonesia.

2) Untuk memperkuat persatuan dan kesatuan bangsa terdapat beberapa prinsip yang menjadi pondasinya. Ada 5 prinsip penting dari UUD 1945 yaitu :

a. Prinsip Bhinneka Tunggal, menjiwai arti Bhinneka Tunggal Ika itu sendiri, yang berarti "berbeda - beda tetapi tetap satu jua". Dengan beragam kebudayaan,ras, dan agama di Indonesia kita diwajibkan bersatu dalam satu bangsa, yaitu bangsa Indonesia.

b. Prinsip Nasionalisme Indonesia, merupakan rasa cinta dan kesetiaan terhadap bangsa Indonesia. Nasionalisme merupakan sikap politik dari masyarakat yang memiliki tujuan dan cita - cita yang sama.

c. Prinsip Kebebasan yang Bertanggung Jawab, maksudnya adalah setiap orang diberi hak untuk memenuhi kemauannya asal tidak menyalahi Hak Asasi Manusia. Jika sampai melanggar dan merugikan orang lain, akan diberikan sanksi berdasarkan perbuatannya.

d. Prinsip Wawasan Nusantara, Wawasan Nusantara dilaksanakan untuk memenuhi tujuan nasional. Memiliki fungsi sebagai pedoman, motivasi, dan rambu-rambu dalam menentukan keputusan untuk menyelenggarakan negara.

e. Prinsip Persatuan Pembangunan, untuk Mewujudkan Cita-cita Reformasi 
Namun hal tersebut tidak membuat bangsa Indonesia merasa unggul dan menganggap rendah bangsa lain, karena itu dapat menodai sila yang terkandung dalam Pancasila.

3) Manfaat dari terciptanya rasa persatuan dan kesatuan sendiri yaitu sebagai berikut:

a. Persatuan dan kesatuan dapat mengatasi semua perbedaan dengan penuh kesabaran dan kesadaran.

b. Persatuan antarwarga negara dapat membuat pembangunan nasional berjalan lancar, aman, baik, dan sesuai harapan.

c. Bangsa Indonesia akan lebih mudah maju dan berkembang dengan menerima perbedaan yang muncul.

d. Tujuan nasional yang tertuang dalam pembukaan UUD 1945 alinea keempat akan lebih mudah untuk dicapai.

e. Dengan adanya persatuan dan kesatuan, akan tercipta suasana yang aman, damai, dan tenteram dalam negara. Terutama karena adanya sikap toleransi, solidaritas, dan setia kawan di antara warganya.

f. Persatuan dan kesatuan dapat mewujudkan kehidupan yang seimbang, harmonis, serta serasi antarmanusia.

g. Pelaksanaan gotong - royong dalam lingkungan sekitar akan berjalan lancar tanpa adanya kendala.

h. Saling menjaga kerukunan dan menjalin silaturahmi antar bangsa.

\section{Daftar Pustaka}

Annurua, Q. A., \& Nurani, F. Tanggung Jawab Dalam Menjaga Persatuan Dan Kesatuan Bangsa Indonesia.

Setianingsih, E., \& Dewi, D. A. (2021). Pentingnya Jiwa Persatuan Dan Kesatuan di Lingkungan Masyarakat Untuk Mendukung Pendidikan Kewarganegaraan. Rhizome: Jurnal Kajian IImu Humaniora, 1(8). 